\title{
The Influence of Firm's Size, Growth, and Profitability on Firm Value with Capital Structure as the Mediator: A Study on the Agricultural Firms Listed in the Indonesian Stock Exchange
}

\author{
Purwohandoko ${ }^{1}$ \\ ${ }^{1}$ Department of Management, State University of Surabaya, Indonesia \\ Correspondence: Priyono, Graduate Master of Management Program of Universitas Bina Darma, Palembang, \\ Indonesia, Indonesia. Tel: 62-812-1697-4878. E-mail: priyono.unu_sidoarjo@yahoo.com
}

Received: June 2, 2017

Accepted: June 21, 2017

Online Published: July 10, 2017

doi:10.5539/ijef.v9n8p103

URL: https://doi.org/10.5539/ijef.v9n8p103

\begin{abstract}
This study aims to examine the effect of size, growth, and profitability on corporate value with capital structure as a mediator.

This study was conducted on agricultural companies listed on the Indonesia Stock Exchange from 2011 to 2014. The population of this study is an agricultural company listed on the Indonesia Stock Exchange period 2011-2014 with a sample of 14 companies, using purposive sampling method. Data were analyzed using smartpal, because this research adds capital structure as mediator variable.
\end{abstract}

The results of this study indicate that firm size and firm growth have no effect on capital structure. Profitability negatively affects the capital structure.

Keywords: size, growth, profitability, capital structure, firm value, agricultural sector

\section{Introduction}

In order to survive in the complex business world, the company must mobilize its forces to achieve corporate objectives, by increasing the value of the company (Hamidy, 2014). Theory of the firm mentioned that the main purpose of a companies is to maximize wealth or enterprise value (value of the firm) (Salvatore, 2005). Higher value of the company will affect to the perception of potential investors which can influence them to be more confidence and belief in to the prospect of a company. The value of the company is the market value of a company's equity plus the market value of the debt. In addition, the value of the company is characterized by a higher rate of return on investment to shareholders (Hermuningsih, 2013). The value of the company usually be ascociated with investor perception about the level of company success. It also be reflected with stock prices. Higher stock price, the higher company's value, than the market would believe not only on today company's performance, but also on the company's prospects in the future.

According to Brigham and Houston (2001), there are several ratio analysis approaches to assess market value, such as price-earnings ratio (PER), price-book value ratio (PBV), market book ratio (MBR), dividend yield ratio and dividend payout ratio (DPR). This study use PBV to measure the company's value. Martono and Harjito (2008) stated that the share price is a reflection of the results of investment decisions, financing, and asset management. The company's value is a measure of the success of the implementation of financial functions. The company's value can be interpreted as the expected value of shareholders' investment (equity market price) and / or expectations of total enterprise value (market value of equity plus the market value of the debt, or the expectations of market prices of assets (Sugihen, 2003).

Company's book value or price-book value (PBV), shows the level of the company's ability to create value relative to the amount of capital invested. Higher PBV means that the company has a higher stock price compared to the book value per share. The higher the stock price, the more successful companies create value for shareholders. When the company is able to creates value, it certainly gives hope to shareholders in the form of greater profit (Sartono, 2001). The proxy also draws on research Simatupang (2011); Kusumajaya (2011); Driffield (2007; Antwi et al. (2012); and Hermuningsih (2013) were used PBV as measure of company value.

Research that has been done by Velnampy and Niresh (2012) proved that the capital structure has significant 
positive effect on firm value. The study was not consistent with research conducted by Eli (2008) who stated that the capital structure has significant negative effect on firm value. Based on the theory and the above results, it appears the direct influence of capital structure to the company's value has not shown consistent results on the relationship between variables

Company must make a decision about the the optimal capital structure (Husnan \& Pudjiastuti, 2004). The managers need to consider the benefits and costs of funding sources, especially in proportion the source of funding, because its the main focus of the capital structure. Sources of funding for the company are divided into two categories, called internal and external funding sources. Internal funding sources can be obtained from retained earnings and depreciation of fixed assets, while external funding can be obtained from the lenders (its called the debt).

There are many factors that affect to the capital structure. Factors that affect the company's capital structure are rate of sales growth, sales stability, industry characteristics, asset structure, manajamen attitude, and the attitude of lenders (Weston \& Copeland, 1996). Weston and Brigham (1997) add operating leverage, profitability, tax control, lender's attitude, assessor credibility, market conditions, the company's internal conditions, and the company's financial flexibility as the factors that can affect to the capital structure of a company. Suad Husnan (2000) states that the factors that affecting capital structure is the distribution location profits, sales and profit stability, dividend policy, funds control the risk of bankruptcy. Meanwhile, Bambang (2001) mention that factors affecting capital structure are interest rate, stability of income, asset composition, asset risk levels, the large amount of capital required, the state of capital markets, the nature of management, the size of a company.

According to Sujoko and Soebiantoro (2007), the increasing size of the company's scale make investors will respond positively on the increasing company's value. According to Gaver and Kenneth (1993), Jaggi and Ferdinand (1999), Prabansari and Hadri (2005), Gul et. al. (2013), and Gathogo and Mary (2014), the size of the company has a significant positive influence on the capital structure. But Esperanca et al (2003) has the opposite conclusion. Another result from Zhang (2010), Pontoh and Ventje (2013), Suresha and Shefali (2013), and Tarus et al. (2001) conclude that the size of the company does not affect significantly to the capital structure.

The company's growth is an indicator or a measurement of how company's development or growth in a given period. It is only a matter of time. According to Brigham and Gapensky (1996), growth of the companies need large funding from external parties. Companies that grow exponentially more likely to use debt rather than the companies that grow slowly (Weston \& Brigham, 1994). Ozkan (2001) also states that the amount of debt being issued by the company is inversely proportional to growth. These results are also similar with research by Bhaduri (2002) as well as Brailsford's (2002). According to Esperanca et al. (2003), Prabansari and Hadri (2005), Gul et al. (2013) and Shieh et al. (2001), the company's growth will affect to the structure of capital. Another case with the same opinions is what has been found by Jeniffer and Kenneth (1993) which states that the growth of the company give significant negative effect to capital structure. Meanwhile, according to Zhang (2010), Wiston and Ventje (2013), and Gathogo and Mary (2014) the company's growth has no effect against the capital structure.

According to Sugiyarso and Winarni (2005), the profitability of the company is the ability to earn profits in relation to sales, total assets as well as its own capital. Profitability became one of the most influential factors in the structure of capital. The company wanted to rise up to a level of profitability that is always high and stable. Companies that have high profitability will reduce debt. This is due to the company's holding the bulk of its profits on earnings withheld to rely on internal resources and relatively reduce the use of debt.

The magnitude of the ratio of DER in 2011 on the agricultural sector experienced a rapid improvement from the previous year compared to the other sectors recorded on BEI i.e. amounting to 8,24\%. However, the ratio of agriculture on DER decreased by $2 \%$ in 2012 and $1.37 \%$ by 2013. This was followed by a decrease in ROE in 2013 to 2014 of 2,81\%. (www.idx.co.id). But according to Ang (1997), the higher Debt to Equity Ratio will affect the magnitude of profit (return on equity) achieved by the company.The purpose of this research is to analyze the effect of size of company, company growth, and profitability of the company's capital structure and firm value on agricultural sector recorded on the Indonesia stock exchange period 2011-2014.

\section{Previous Studies}

A study by Gaver and Kenneth (1993) about capital structure, using two variables, size of the company and the company's growth, as the independent variabel. The results of their study is the size of the company has significant positive effect to the structure of capital, but the company's growth appear has significant negative effect of capital structure.

Jaggi and Ferdinand (1999) also doing research that was held in Hong Kong. Their research using the multiple 
regression analysis, and found that each of the size of the company and free cash flow has positive effect to the structure of capital. The argument was that free cash flow has positive effect especially when growth opportunities is low. The results of the research also indicate that there is a positive relationship between debt and growth on corporate FCF is low, especially in large companies. The higher debt levels, the more funds needed and more companies will choose to go to the market for debt rather than equity markets. The reason was because the debt will be relatively cheaper for them. In addition, it would be easier to regulate the debt because of the risk of bankruptcy is relatively low.

Prabansari and Kusuma (2005) has been conducting quantitative research about capital structure using size, the company's growth, profitability, risk and ownership structure. The study stated that the size, sales growth, profitability, and the structure of ownership has significant positive effect to the structure of capital. But the risk has a significant negative effect of capital structure. The company will have a higher sales growth when the company using more debt in their capital structure.

Zhang (2010) using profitability, growth company, tangibilitas, the size of the company, and the company's capital structure against age. He was doing his research in Beijing, China. His study concludes that the fifth independent variables have no effect significantly to capital structure.

Research of Suresha and Shefali (2013) used five independen variable, such as liquidity, size of company, product variability, profitability, and tangibilitas. For variable liquidity, size, product, and variability, and tangibility have no significant effect to capital structure. But for the profitability has significant negative effect on capital structure. Large companies have more long-term debt. Large companies reflect the low level of risk and a stable rate of return on the lender, because the big companies can borrow more funds. The company's credibility is higher because of the possibility of default is lower. The more debt, corporate resources will be increased and this can cover any losses on a greater extent so as to allow the company do more loan. The loan will significantly reduce taxes.

Gul et al. (1995) in his research states that the profitability, liquidity has significant negative effect of capital structure. While the variable size of the companies, tangibilitas and company growth a significant positive effect on capital structure. And non-tax debt has no effect against the capital structure. The profitability of the negative effect in accordance with the theory of the pecking order that States that the higher the profitability of companies, then the company will prefer internal funding rather than external funding. The liquidity effect is negative because the banking companies tend to keep liquidity remains high, so it can produce a high cash flow, then the excess cash can be used to finance their projects. The companies with high liquidity, less dependent on debt compared to companies with low liquidity. This is in accordance with the trade of theory which States that larger companies can provide a greater amount of debt in its capital structure because it has a more consistent cash flow and a smaller risk.

Pontoh and Ventje (2014) in his study of capital structure using growth of the company, tangibilitas, the size of the company, and the influence of the level of operations as independent variables. The results obtained in the study that all the dependent variable have no effect against the capital structure. Big companies would give priority to internal funding. This aims to create a more stable cash flow. In addition, to cope with business risks, big companies will keep its capital structure and does not use debt.

Gathogo and Mary (2014) doing research in Kenya stated that the variable size of the company and the risk has significant positive effect to the capital structure. While the profitability, liquidity have significant negative effect of capital structure. The cost of debt and growth do not affect significantly to capital structure. Influential business risk due to a positive culture of investors in Kenya that tend to avoid risks and less trusting to investors from foreign countries. So when business increases risk, then investors will stay away from the shares so that the company will be hard-pressed to increase the amount of equity of the stock market.

Research conducted by Shieh et al. (2001), state that debt interest, profit, and the growth of the company's significant positive will give influence to the structure of capital. But when they add tax credits in their study, the result said that there are negative effect the profitability of capital structure. Whereas the tariff margin corporate taxes have no effect against the capital structure.

Tarus et al. (2001) in their research from Kenyan Firms Listed, show that profitability and liquidity will have a significant negative influence to the structure of capital. As for the variable size of the companies in his work generate no effect significantly to capital structure. 
Table 1. Research variable

\begin{tabular}{ll}
\hline Variable & Proxy \\
\hline Firm's Value & PBV = shows the level of the company's ability to create value relative to the amount of capital invested. \\
& PBV = Market price of stock / Book value \\
Capital structure (Y) & DER (Debt to equity ratio $)=$ Debt total equity \\
Company's size (X1) & SIZE = Ln total asset \\
Company's growth (X2) & GROWTH = (annual total asset t - annual total asset t-1)/ annual total asset t-1 \\
Profitability (X3) & ROE = interest after tax/ total equity \\
\hline
\end{tabular}

\section{Reseach Method}

This research is quantitative research using secondary data. The company used as samples in this study is the whole company in the agricultural sector recorded on the Indonesia stock exchange period 2011-2014 and have the full financial report. Data analysis was conducted by PLS (Partial Least Square). PLS is an alternative method of SEM-based variance. PLS estimates the statistical parameters that describe some variance to the maximum as happened in the OLS regression analysis (Hair et al., 2010). The hypothesis will be tested using the software smartPLS.

The focus of research based on the formulation of the problem and the hypothesis of this the study is the relationship between variables, which indicate a causal relationship complex and tiered. These relationships involve endogenous variables, namely the size, growth and profitability; exogenous variables, namely capital structure and firm value. The problems that have the characteristics of hierarchical relationships and types of variables such as these require analysis techniques that can be used equation estimation techniques silmutanus with path analysis (Hair et al., 2006).

\subsection{Hyphothesis Testing on the Influence of Company's Capital Structure}

\subsubsection{The Influences of the Size of the company's Capital Structure}

The size of the company is the estimator shows her little big company. The size of the company can be assessed from several establishments. Big nothingness of a company can be based on the total value of the total assets, sales, market capitalization, the amount of labor and so on. The greater the assets of a company will be the bigger capital also planted, the greater the total sales of a company it will be more and more turnover and also the greater market capitalization then the bigger companies are known to the public (Hilmi \& Ali, 2008)

Large or small size companies will mainly describe the company. A lot of things that can be seen to describe the size of a company. Among other things is to look at the total sales, and total assets. This is in accordance with the statement of the Ferry and Jones (1979), size large small companies describe an enterprise indicated by total assets, the amount of sales, the median average total sales - median - median and total assets. According to George and Marry (2014), Sajid et al. (2013), Bikki and Ferdinand (1999), Jenifer and Kenneth (1993), and the Yuke and Hadri (2005) states that the size of the company's significant positive effect to the structure of capital. Because the higher the size of the company's assets will be the higher level of debt the company uses.

H1: Company Size (SIZE) has significant positive effect to the structure of capital.

\subsubsection{The Influences of the Size to Firm's Value}

According to Dewi and Wirajaya (2013) the size of a company increases from the fact that large companies have large market capitalization; book value is large and high profit too. Investors tend to be more interested in companies with large scale. This is because large companies tend to have a more stable condition. This stability attracts investors to own shares in the company, and this will cause a rise in share price in the capital market. It can be said that size has an influence on company values.

H2: Company Size has significant positive effect to the firm value.

\subsubsection{The Influences of the Growth of the Company's to Capital Structure}

Assets is assets used for operating activities of the company. The larger assets, expected operating results generated by the company are also getting bigger. According to Halim (2005) the company's growth is change (growth rate) of annual total assets. Total assets will change at each period depending on condition of the economy both internal and external to the enterprise. The company's growth also influence on capital structure. This agreed with Sajid et al. (2013), Wen et al. (2014), Jose et al. (2003), and the Yuke and Hadri (2005) who in his research menyatkan that company growth a significant positive effect on capital structure. The cause of this is due to the higher growth of the company, it will be the lower of the company to use its debt level. 
H3: Company growth (GROWTH) has significant positive effect on capital structure.

\subsubsection{The Influences of the Growth to Firm's Value}

Growth is the impact of cash flow of the company's operational changes due to increase or decrease in business volume (Kusumajaya, 2011). Companies with high potential growth rate have a tendency to generate high cash flows in the future and high market capitalization that will attract investors to invest. The value of the company formed by indicators of stock market value is influenced by investment opportunities. The existence of investment opportunities can provide a positive signal about the company's growth in the future, so as to enhance shareholder value. It can be said that growth has influence on company values.

H4: Company growth (GROWTH) has significant positive effect on firm value.

\subsubsection{The Influence of Profitability toward Capital Structure}

Profitability is the ability of a company to acquire a good profit from the sale of the company's investment or by utilizing the sources of their funds from either internal or external. According to Sugiyarso and Winarni (2005) the profitability of the company is the ability to earn profits in relation to the total sales of assets as well as its own capital.

In its profitability has a negative relationship to the structure of capital. The higher the profitability of a company so the quicker the return on his investment. In a study conducted by Esperanca et al. (2003) stated that the profitability of the significant negative effect of capital structure. This is in line with the opinion of the Brigham and Houston (2001), which says that companies with a high rate of return on investment will use debt is relatively small. So the higher the level of profitability of the company then the company's debt levels will also be getting smaller.

H5: Profitability (PROF) has significant negative effect of capital structure.

\subsubsection{The Influences of the Profitability to Firm's Value}

According to Husnan and Pudjiastuti (2011, p. 183) an investment is said to be, if the investment could make investors wealthier. In other words, the investor becomes greater in prosperity after investing. This understanding is consistent with the objective of maximizing the value of the company. The most important thing for the company is how to maximize the profit of shareholders, and not how much profit is generated by the company. Profitability is the company's ability to make a profit. The investors have shares in other to get a return. The higher the ability of the company to make profit, the greater the expected return of investors, making the value of the company better.

H6: Profitability (PROF) has significant negative effect of firm value.

\subsubsection{The Influences of the Capital Structure to Firm's Value}

Brigham and Houston (2010, p. 183) explained the relationship between capital structure and corporate value through the Tradeoff Theory. They elucidated that companies exchange tax benefits of debt financing with the problems raised by the potential bankruptcy. According to Atmaja (2008, p. 254), Modigliani-Miller concluded that the use of debt (leverage) will increase the value of the company if the cost of interest on debt is a cost that reduces the payment of taxes (a taxdeductible expense). On the other hand, Tradeoff Theory explains that if the position of the capital structure is under optimal point, then any additional debt will increase the company's value. Conversely, if the position of each capital structure is above the optimal point, then any additional debt would lower the value of the company. It can be said that capital structure has an influence on company values.

H7: Capital Structure has significant positive effect on firm value.
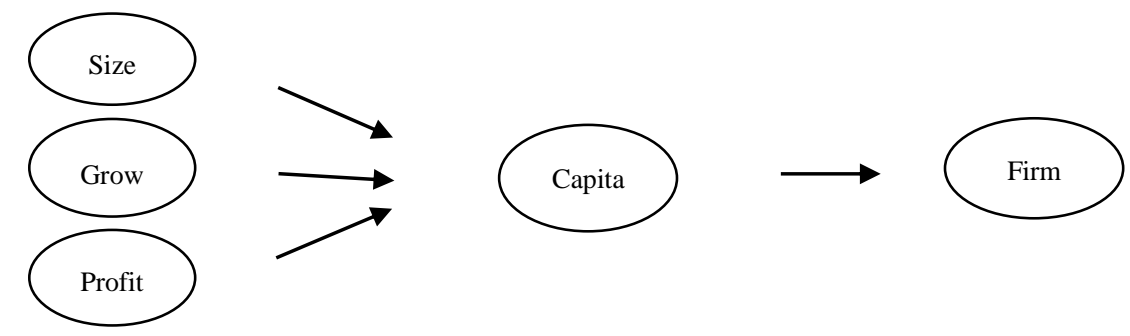

\subsection{Scope of the Research}

This research examines the entire agricultural sector companies listed on the Indonesia stock exchange in 2011-2014. The election of Indonesia stock exchange because financial data is presented. And research in the 
agricultural sector because companies in the agricultural sector is still growing and there is a decrease in DER phenomenon is directly proportional to the decrease in ROE. For it to do the research to find out what factors can influencing capital structure on firms in the agriculture sector the period 2011-2014.

\subsection{Sample}

Sampling technique used was purposive sampling technique. Purposive sampling method is the technique of determination of samples with specific consideration. Purposive sampling was done by taking a subject is not based on the strata, random, or the region but based upon the existence of a particular purpose. Sample criteria in this study is the whole company which has a full financial report on the agricultural sector recorded on the Indonesia stock exchange period 2011-2014.

Table 2. Sampling criterion

\begin{tabular}{llc}
\hline No & Criteria & Total \\
\hline 1 & Agricultural company sectors listed in BEI 2011-2014 & 20 \\
2 & Agricultural company sector which do not hold their total reporting during 2011-2014 & -6 \\
\hline Sampling total & 14 \\
\hline
\end{tabular}

\subsection{Data Source}

Secondary data used are sourced from corporate financial report data published in the Indonesia stock exchange. The data used is the annual financial reports of the company's data during the 4 years that is starting from the period 2011 to 2014.

\section{Hipothesis Testing Result}

This part reports hippthesis testing results from the analysis of $\mathrm{H} 1, \mathrm{H} 2$, dan $\mathrm{H} 3$.

Table 3. Regression testing

\begin{tabular}{lcccc}
\hline Variabel & Coefficients & t-statistic & Probability & VIF \\
\hline SIZE & 0,028 & 0,336 & 0,783 & 1,008 \\
GROWTH & 0,054 & 0,639 & 0,526 & 1,026 \\
PROF & $-0,806$ & $-9,615$ & $0,000^{*}$ & 1,024 \\
f-statistic & & 31,244 & $0,000^{*}$ & \\
Ad R $\mathbf{2}^{2}$ Square & 0,623 & & & \\
\hline
\end{tabular}

Description: *significant under $5 \%$ of significant level.

Source: the researcher's data analysis (2016).

Of these three variables are free above the size of the company (size), company growth (growth), and profitabilias, there is one variable that qualify the significance of 5\% that is the variable profitability. Based on table 3, it can be seen that the level of significance of company size (size) is 0.783 and the level of significance of company growth (growth) of their significance and value $0.526>0.05$ then it can be inferred is not found among variables influence the size of the company and company growth (growth) against the capital structure (debt ratio). While the level of significance of the variables of profitability (ROE) of 0.000. Because the value of the variable significance of the profitability of less than 0.05 and the value of the coefficient of 0.806 then it can be inferred, there is negative influence among variables of profitability (ROE) against the capital structure (debt ratio). The results of table 3 shows that the adjusted $R$ square value was amounting to 0.623 . This indicates that the variation of the independent variable are together able to explain variation in the dependent variable $62.3 \%$, while the rest i.e. $37.7 \%$ explained by variables other than the independent variable.

\subsection{The Result of H1 Testing}

Company size (size) have no effect against the capital structure (debt ratio). This is evidenced by the value the significance of variable size that exceeds 0.05 i.e. amounting to 0.783 . The results of this research with Zhang sesui (2010), Pontoh and Ventje (2013), Suresha and Shefali (2013), and Tarus et al. (2001) which States that the size of the company do not affect significantly to capital structure. According to Pontoh and Ventje (2013) are large enterprises will give priority to internal funding. This aims to create a more stable cash flow. In addition, to cope with business risks, big companies will keep its capital structure and does not use debt. So the size of the company doesn't have an effect on the structure of capital. 


\subsection{The Result of $\mathrm{H} 2$ Testing}

The value of the variable significance of 0.526 company growth and greater than 0.05 . It is evident that the growth of the company does not have an effect on the structure of capital. These results are in accordance with research of Zhang (2010), Wiston and Ventje (2013), and Gathogo and Mary (2014) by which stating that the company's growth has no effect significantly to capital structure. Results peenelitian Gathogo and Mary (2014) stated that the growth of investment in developing countries is not as large as in the developed countries where the purpose of the company is developed countries into the global market. As such, the company does not need a lot of funds to meet the investment growth. In addition, because companies in Indonesia are likely to choose to use debt rather than investment. So it was concluded that the company's growth has no effect against the capital structure.

\subsection{The Result of H3 Testing}

Based on the test results, the value of the significance of the profitability of less than 0.05 and the value of the coefficient of 0.806 then it is evident that there is a negative influence among variables of profitability (ROE) against the capital structure (debt ratio). This is in accordance with the research Esperanca et al. (2003) stating that the profitability of a significant negative effect of capital structure. Brigham and Houston (2001) says that companies with a high rate of return on investment will use debt is relatively small. So the higher the level of profitability of the company then the company's debt levels will also be getting smaller.

\section{Conclusion}

Based on the research results and discussion can be concluded that the size of the company, company growth, and profitability together effect on capital structure (debt ratio) the agricultural sector company listing on the Indonesia stock exchange (idx) on a research period 2011-2014. In partial results of the study are outlined as follows: the company's size has no effect on the capital structure (debt ratio), the company's growth has no effect on the capital structure (debt ratio), the negative effect on the profitability of the capital structure of the company's agricultural sector in Indonesia stock exchange listing period 2011-2014.

The researchers next expected could do similar research by replacing the proxy with proxy DER LTDE. For investors, before making investments they should be suggested to looking at the magnitude of the resulting companies profit from the previous year. Because it is proven that the effect on profitability of capital structure to see whether strong internal funds the company or to see how large the value of debt which becomes the obligation burden of the company.

\section{References}

Ali, \& Hilmi. (2008). Analysis of Factors Affecting Financial Reports Timeliness. Journal of Business and Accountancy.

Ang, R. (1997). Book Smart Indonesian Capital Market. Jakarta: Indonesia Mediasoft.

Arikunto, S. (2006). Research Procedure A Practical Approach. Jakarta: PT. Rineka Reserved.

Bhaduri, S. N. (2002). Determinants of Loan Company: Some Evidence From India Corporate Structure. Journal of Economics and Finance. https://doi.org/10.1007/BF02755986

Brailsford, T. (2002). On the Relationship Between Ownership Structure and Capital Structure. Journal of Accounting and Finance. https://doi.org/10.1111/1467-629X.00001

Brigham, E. F. (1983). Fundamentals of Financial Management (3rd ed.). Holt-Saunders Japan: The Dryden Press.

Brigham, E. F., \& Houston. (2006). Fundamentals of Financial Management. Interpreting Ali Akbar Yulianto. Jakarta: Four Salemba.

Brigham, E. F., \& Houston, J. F. (2001). Financial Management. Jakarta: Four Salemba.

Brigham, E., \& Gapenski. (1996). Intermediate Financial Management. Harbor Drive: Dryden Press.

Cooper, D. R., \& Schindlers. (2006). Business Research Methods. Jakarta: PT. Global media.

Donaldson, C. (1961). Company Debt Capacity: A Study of Corporate Debt Policy and Debt Capacity Determination companies. Boston: Harvard School of Business Administration.

Esperanca, J. P., Gama, A. P., \& Gulamhussen, M. A. (2003). Debt Policy Company Small Company: A re empirical (examination). Journal of Small Business and Enterprise Development, 10(1).

Ferry, M., \& Jones, W. (1979). Determinants of Financial Structure: Approach the new methodology. Journal of 
Finance, XXXXIV(3). https://doi.org/10.1111/j.1540-6261.1979.tb02130.x

Gathogo, G., \& Ragui, D. M. (2014). The Company's capital structure Kenya: What Determines It? Research Journal of Finance and Accounting, 5(5).

Gaver, J. J., \& Gaver, K. M. (1993). Additional Evidence On The Association Between The Investment Opportunity Set and Corporate Financing, Dividend, and Pompensation Policy. Elsevier Science, 16(1993), 125-160.

Ghozali, I. (2011). Multivariate Analysis Application Program Article Search Google IBM SPSS 19 (5th ed.). Semarang: Diponegoro University Publishers Agency.

Gul, S., Khan, M. B., Razzaq, N., \& Saif, N. (2012). How Firm Characteristics Affect the Capital Structure in Banking and Insurance Sector (Case Pakistan). European Journal of Business and Management, 4(12).

Halim, A. (2005). Investment Analysis. Jakarta: Four Salemba.

Harahap, S. (2006). Critical Analysis of Financial Statements (1st ed.). Jakarta: King Grafindo Persada.

Haugen, R. A., \& Pappas, J. L. (1971). Of Equilibrium In the Capital Asset Pricing, Risk-bearing debt, and The Question On Optimal Capital Structure. Journal of Financial and Quantitative Analysis. https://doi.org/10.2307/2329913

Husnan, S. (2000). Financial Management Theory and Application (Short-Term Decisions). Yogyakarta: Yogyakarta BPFE.

Jaggi, B., \& Gul, F. A. (1999). Joint Analysis of Effect of the investment opportunity set, and Free Cash Flow Measures in Corporate Debt Policy. Review of Quantitative Finance and Accounting, 12(1999), 371-381. https://doi.org/10.1023/A:1008354509316

Jensen, M. C., \& Meckling, W. (1976). Theory of the Firm: Managerial Behavior, Agency Costs and Ownership Structure. Journal of Financial Economics. https://doi.org/10.1016/0304-405X(76)90026-X

Megginson, W. (1997). Theory of Corporate Finance. Wesley Educational Publishers, Inc.

Modigliani, F., \& Miller, M. (1958). Cost of Capital, Corporation Finance and Investment Theory. American Economic Review.

Myers, \& Brealey. (1991). Principles of Corporate Finance (4th ed.). WE.

Myers, S., \& Majluf, N. (1984). Corporate Financing and Investment Decisions When Firms Have Not Had Investor Information. Journal of Financial Economics. https://doi.org/10.1016/0304-405X(84)90023-0

Nugroho, A. S. (2006). Analysis of Factors Affecting Capital Structure The Property Company Go Public In Jakarta Stock Exchange to Period Year 1994-2004. Published thesis. Semarang: Diponegoro University.

Ozkan, A. (2001). Determinants of Capital Structure And Adjustment For Long Term Target: Evidence From UK Company Panel Data. Journal of Business Finance \& Accounting. https://doi.org/10.1111/1468-5957.00370

Pontoh, W., \& Physical Defect, V. (2013). Structural determinants of Capital and Profitability Impact (Study Companies Listed in Indonesia Stock Exchange). Research Journal of Finance and Accounting.

Prabansari, Y., \& Kusuma, H. (2005). Factors Affecting Capital Structure Manufacturing Companies Go Public in Jakarta Stock Exchange. Synergies: Special Edition on Finance.

Purwohandoko. (1999). Empirical Study of the Relationship Between Profitability Expected for Google Pages Beta on Shares Traded on Jakarta Stock Exchange Capital Asset Pricing Model Approach. Malang: Unpublished.

Ragui, G. G. (2014). The Company's capital structure Kenya: What determines it? Research Journal of Finance and Accounting.

Riyanto, B. (2011). Fundamentals of Company Spending (4th ed.). Yogyakarta: Yogyakarta BPFE.

Ross, S. (1977). The Determination of Financial Structure: The Incentive-Signalling Approach. The Bell Journal of Economics, 8(1), 23-40. https://doi.org/10.2307/3003485

\section{Copyrights}

Copyright for this article is retained by the author(s), with first publication rights granted to the journal.

This is an open-access article distributed under the terms and conditions of the Creative Commons Attribution license (http://creativecommons.org/licenses/by/4.0/). 